\title{
Interferon- $\lambda$ in the Context of Viral Infections: Production, Response and Therapeutic Implications
}

\author{
Pascale Hermant Thomas Michiels \\ de Duve Institute, Université Catholique de Louvain, Brussels, Belgium
}

\section{Key Words}

Epithelium · Hepatitis C virus · Host defense - Interferon . IFNAR · IFNLR1 · IL-28 · IL-29 · RNA virus · Virology

\begin{abstract}
Interferon (IFN)- $\lambda$ forms the type III IFN family. Although they signal through distinct receptors, type I (IFN- $\alpha / \beta$ ) and type III IFNs elicit remarkably similar responses in cells. However, in vivo, type III and type I IFN responses are not fully redundant as their respective contribution to the antiviral defense highly depends on virus species. IFN- $\lambda$ is much more potent than IFN- $\alpha / \beta$ at controlling rotavirus infection. In contrast, clearance of several other viruses, such as influenza virus, mostly depends on IFN- $\alpha / \beta$. The IFN- $\lambda$ receptor was reported to be preferentially expressed on epithelial cells. Cells responsible for IFN- $\lambda$ production are still poorly characterized but seem to overlap only partly IFN- $\alpha / \beta$-producing cells. Accumulating data suggest that epithelial cells are also important IFN $-\lambda$ producers. Thus, IFN- $\lambda$ may primarily act as a protection of mucosal entities, such as the lung, skin or digestive tract. Type I and type III IFN signal transduction pathways largely overlap, and cross talk between these IFN systems occurs. Finally, this review addresses the potential benefit of IFN- $\lambda$ use for therapeutic purposes and summarizes recent results of genome-wide association studies that identified polymorphisms in the region of the IFN- $\lambda 3$ gene impacting on the outcome of treatments against hepatitis $C$ virus infection.
\end{abstract}

๑) 2014 S. Karger AG, Basel

\section{KARGER}

(c) 2014 S. Karger AG, Basel

1662-811X/14/0065-0563\$39.50/0

E-Mail karger@karger.com

www.karger.com/jin

\section{Introduction}

Ten years ago, interferon (IFN)- $\lambda$ was discovered by two independent groups $[1,2]$. IFN- $\lambda$ forms the type III IFN family, which is composed of three members, IFN- $\lambda 1$, IFN- $\lambda 2$ and IFN- $\lambda 3$, also named IL-29, IL-28A and IL$28 \mathrm{~B}$, respectively $[1,2]$. Recently, a fourth IFN- $\lambda$ subtype, named IFN- $\lambda 4$, has been described in humans [3]. It is expressed in a small fraction of the human population as a consequence of a frameshift occurring in a coding sequence, upstream of the IFNL3 gene. This IFN only bears $29 \%$ identity with IFN- $\lambda 3$ but acts through the same receptor and displays typical antiviral activity [4].

Genes encoding IFN- $\lambda$ map on chromosome $19 q 13$ in humans and $7 \mathrm{~A} 3$ in mice $[1,2,5]$. In mice, IFN- $\lambda 1$ is a pseudogene [5]. Unlike most type I IFN genes, which are intronless, type III IFNs have several exons, 5 for IFN- $\lambda 1$ and 6 for IFN- $\lambda 2$ and IFN- $\lambda 3$ [2]. In humans, IFN- $\lambda 4$ was shown to be $\mathrm{N}$-glycosylated and IFN- $\lambda 1$ contains a potential $N$-glycosylation site $[4,6]$. In mice, both IFN- $\lambda 2$ and IFN- $\lambda 3$ are $\mathrm{N}$-glycosylated [5].

Type III IFNs signal through a heterodimeric cell surface receptor composed of two chains: IFNLR1, which is specific to IFN- $\lambda$, and IL10RB, which is shared by other IL-10-related cytokines $[1,2,7]$. Type I IFNs use a different receptor (IFNAR), which is composed of subunits IFNAR1 and IFNAR2c. However, upon binding their cognate receptors, type I and type III IFNs trigger the

Dr. Thomas Michiels

de Duve Institute, Université Catholique de Louvain, B1.74.07 VIRO

74 Avenue Hippocrate

BE-1200 Brussels (Belgium)

E-Mail thomas.michiels@uclouvain.be 
same Jak-STAT signal transduction pathway $[5,8,9]$ (fig. 1), leading to the upregulation of many genes, called IFN-stimulated genes (ISGs) [reviewed in 10]. More than 300 ISGs have been identified. Their products act to control viral infection, to modulate immune responses or to control mitosis. In addition, some ISGs encode factors that participate in the IFN signal transduction pathway and, therefore, control IFN expression and response through positive or negative feedback loops (fig. 1).

When type I and type III IFN receptors are expressed by a single cell line, triggering either receptor complex leads to the upregulation of the same set of ISGs [11]. Therefore, a major question that arose after the discovery of IFN- $\lambda$ was whether type I and type III IFN responses were redundant in vivo.

\section{Antiviral Activity of IFN- $\lambda$ in Mice}

One of the first evidence-based studies reporting IFN- $\lambda$ antiviral activity in vivo was published by Ank et al. [8], who observed that intravaginal treatment of female mice with IFN- $\lambda$ prior to infection with herpes simplex virus (HSV)-2 prevented virus replication in the vaginal mucosa. Next, analysis of IFN- $\lambda$ antiviral activity in vivo largely benefited from the development of IFN- $\lambda$ receptor-deficient mice (IFNLR $1^{0 / 0}$ ) [12]. By comparing viral infection in wild-type, IFNLR $1^{0 / 0}$, IFNAR ${ }^{0 / 0}$ and double-knockout mice, it was shown that the contribution of IFN- $\lambda$ to the control of viral infection greatly varied according to the virus [13]. Table 1 and figure 2 recapitulate currently available data.

In spite of the efficacy of IFN- $\lambda$ treatment observed against HSV-2, IFNLR1 deficiency did not substantially affect HSV-2 replication. In contrast, IFNAR1 deficiency strongly increased HSV-2 replication [12]. Thus, efficacy of IFN- $\lambda$ against HSV-2 infection in vivo was modest compared to that of type I IFN. Additional studies showed no protective effect of IFN- $\lambda$ against infection with encephalomyocarditis virus, lymphocytic choriomeningitis virus or vesicular stomatitis virus $[8,12]$. Similarly, no antiviral activity of IFN- $\lambda$ could be detected in mice against hepatotropic viruses such as Rift Valley fever virus, Lassa fever virus or a mutant strain of Thogoto virus (THOV) lacking the IFN-antagonist ML protein $(\Delta \mathrm{ML})$ $[14,15]$. The lack of IFN- $\lambda$ antiviral activity against these viruses was not due to a lack of IFN- $\lambda$ expression in infected organs since IFN- $\lambda$ was transcriptionally active in the liver of mice infected with THOV- $\Delta \mathrm{ML}$ [14]. Yet, in spite of IFN- $\lambda$ expression, THOV and Rift Valley fever virus failed to induce Mx1 expression in infected livers of $\mathrm{Mx}^{+/+}$mice lacking functional type I IFN receptors $\left(\right.$ IFNAR $\left.^{0 / 0}\right)$ [14].

IFN- $\lambda$ was found to have a modest but detectable antiviral activity in vivo against influenza virus, human metapneumovirus and severe acute respiratory syndrome coronavirus. For these viruses, mice lacking both receptors turned out to be significantly more susceptible than IFNLR $1^{0 / 0}$ mice [14-16]. Additional studies carried out with influenza virus showed variable extents of protection mediated by IFN- $\lambda$ : two studies reported that IFN- $\lambda$ was of moderate importance against influenza virus (strains SC35M, PR8- $\Delta \mathrm{NS1}, \mathrm{A} / \mathrm{HH} / 05 / 2009$ and B/Lee/ 40) $[14,15]$ and one study observed a major role for IFN- $\lambda$ (strain A/HK-X31) [16]. Such differences in influenza virus control might relate to variations in the ability of the different virus strains to spread systemically from the respiratory epithelium [16].

Contribution of IFN- $\lambda$ was much clearer in the case of respiratory syncytial virus [15]. Indeed, control of respiratory syncytial virus infection depended equally on the presence of type I and type III IFN receptors. Interestingly, IFN- $\lambda$ was shown to play a major, nonredundant, role in the protection against rotavirus infection [17]. IL$28 \mathrm{Ra}^{0 / 0}$, and double-knockout mice were highly susceptible to oral rotavirus infection, while IFNAR ${ }^{0 / 0}$ and wild-type mice were resistant. Moreover, administration of IFN- $\lambda$ allowed the control of rotavirus infection in mice, while administration of IFN- $\alpha$ did not. IFN- $\lambda$ thus appears to contribute much more than type I IFNs to the protection against rotavirus [17].

\section{Cellular Response to IFN- $\lambda$ and Receptor Distribution}

The receptor chain that is specific for IFN- $\lambda$ was first identified in humans $[1,2,7]$. It has been discovered simultaneously by three different teams and called IL-28Ra [2], LICR2 [7] or CRF2-12 [1]. It is now most commonly referred to as IFNLR1. By associating with the $\beta$ chain of the IL-10 receptor (IL10RB), it forms the heterodimeric receptor necessary for IFN- $\lambda$ signaling. The murine receptor has also been characterized [5]. Mouse IFNLR1 shares about $67 \%$ similarity with the human receptor and is encoded by a gene present on mouse chromosome $4 \mathrm{D} 3$. Interestingly, unlike type I IFNs, mouse and human IFN- $\lambda$ are not species specific and can bind the receptors of both species [5]. 


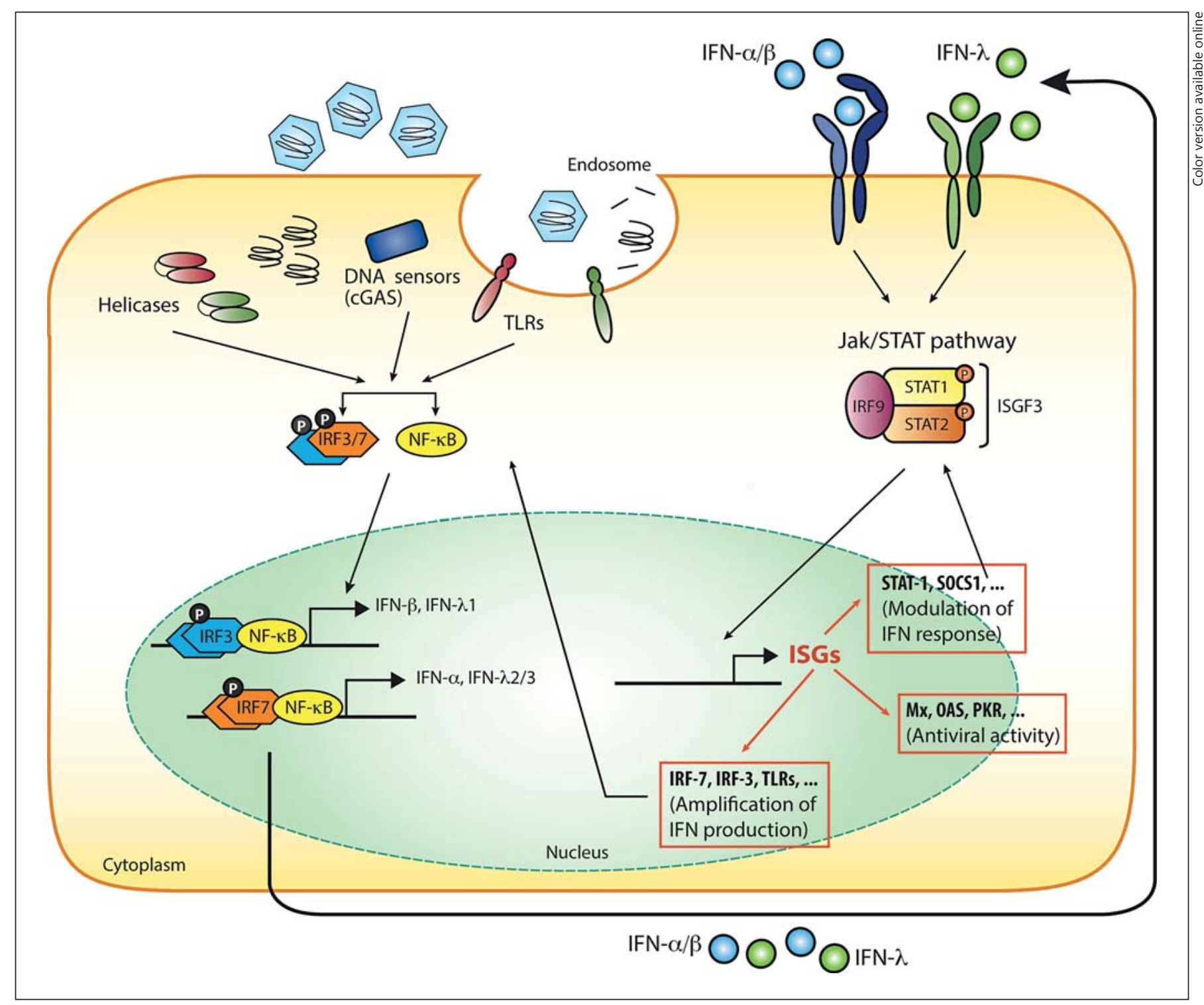

Fig. 1. Type I and type III IFN signal transduction pathways. Viral nucleic acids are recognized by transmembrane TLRs, cytoplasmic DNA sensors and RNA helicases, leading to the activation of kinases. These kinases promote the activation of the NF- $\kappa B$, IRF3 and IRF7 transcription factors and their subsequent translocation to the nucleus where they stimulate IFN gene transcription. IFN- $\lambda 1$ and IFN- $\beta$ gene expression largely depends on IRF3 and NF- $\kappa \mathrm{B}$. Expression of IFN- $\lambda 2$ and IFN- $\lambda 3$, like that of IFN- $\alpha$, depends more on IRF7 availability. Type I IFNs use a dimeric receptor composed of IFNAR1 and IFNAR2c. Type III IFNs signal through a different receptor, which is composed of IFNLR1 and IL10RB. Upon binding to their cognate receptors, type I and type III IFNs induce the same Jak/STAT pathway: the transphosphorylation and activation of receptor-associated Jak1 and Tyk2 leads to the phosphorylation of STAT1 and STAT2 transcription factors. Phosphorylated forms of STAT1 and STAT2 further associate with IRF9 to form a heterotrimeric ISG factor 3 (ISGF3) complex. ISGF3 then translocates to the nucleus where it binds to sequences of IFN-stimulated response elements present in the promoter of ISGs to upregulate their transcription. Some ISG products participate themselves in the signaling pathways leading to IFN production and IFN responses thus creating positive (and negative) feedback loops. Given the similarity of type I and type III IFN pathways, IFN- $\lambda$ is expected to influence both the production of and response to IFN- $\alpha / \beta$, and vice versa. $c G A S=$ Cyclic GMP-AMP synthase. 


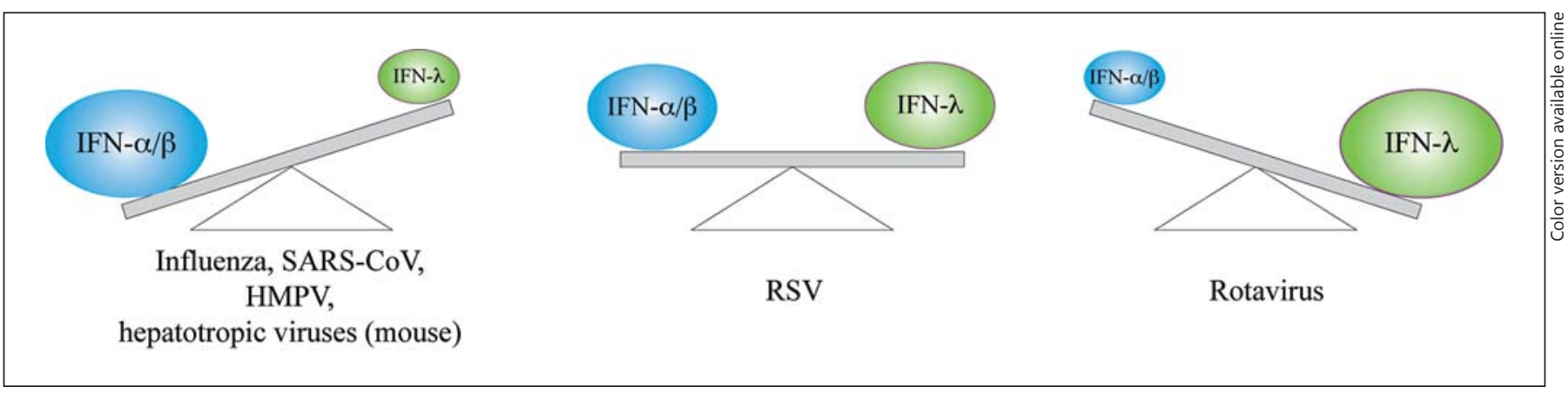

Fig. 2. Relative contributions of type I and type III IFNs in antiviral protection: cartoon illustrating the relative weight of IFN- $\lambda$ versus IFN- $\alpha / \beta$ in the control of viral infection. These data were deduced by comparing viral loads in mice deficient for either receptor. HMPV = Human metapneumovirus; RSV = respiratory syncytial virus; $\mathrm{SARS}-\mathrm{CoV}=$ severe acute respiratory syndrome coronavirus.

Table 1. IFN- $\lambda$ efficacy against viral infections

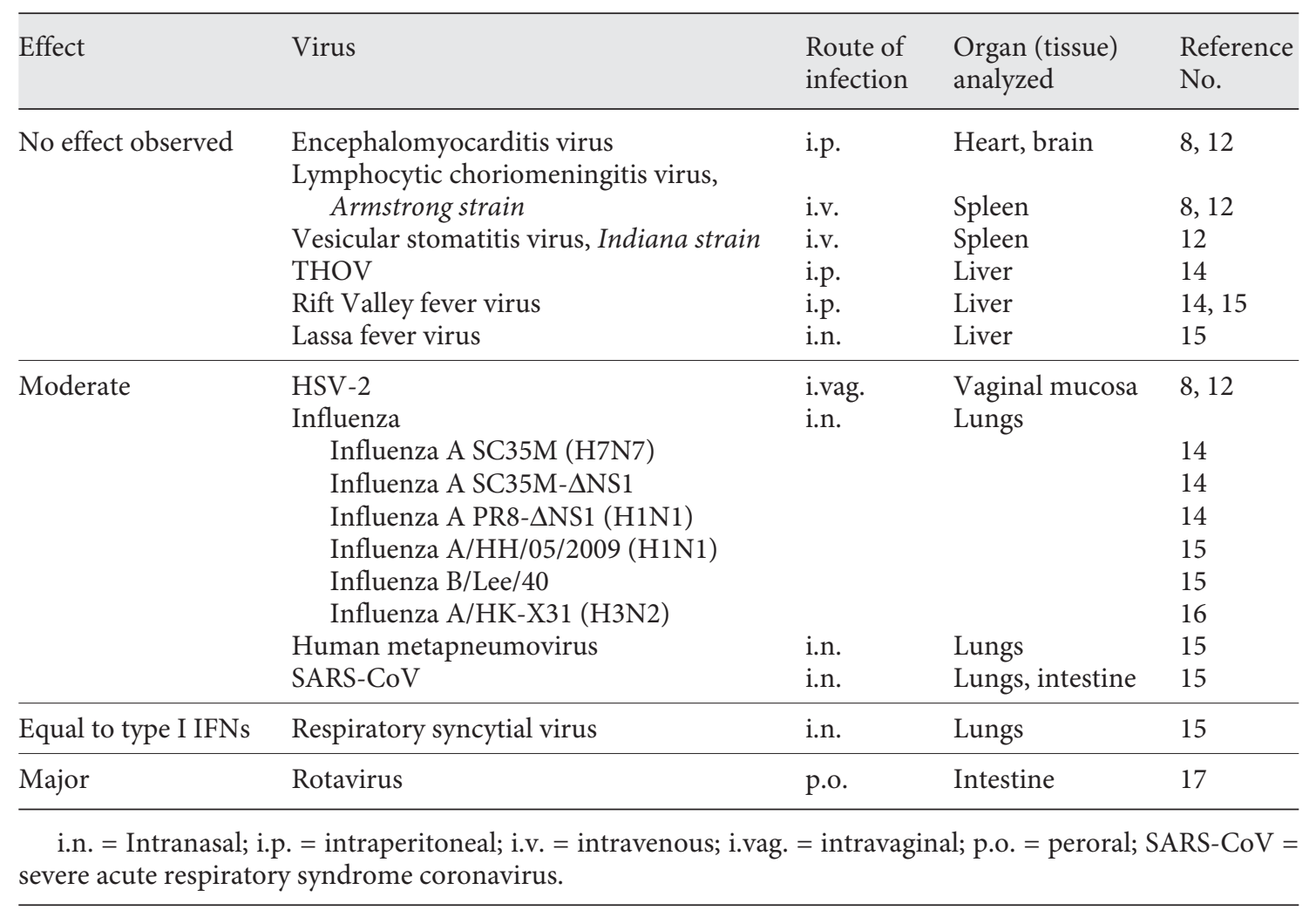

\section{Epithelial Specificity of the IFN- $\lambda$ Response}

Unlike the type I IFN receptor, which is ubiquitously expressed, the type III IFN receptor - especially the IFNLR1 chain - displays a much more restricted cellular distribution $[1,2,5,18]$.
Several studies examined the responsiveness of human and mouse cell lines and primary cells to IFN- $\lambda$ (table 2). Unsurprisingly, IFN- $\lambda$ responses correlated with IL-28R $\alpha$ expression [11]. Fibroblasts, splenocytes, bone-marrowderived macrophages and endothelial cells did not re- 
spond to IFN- $\lambda$, although they responded to IFN- $\alpha$. In contrast, mouse melanoma cells and keratinocytes responded to IFN- $\lambda[5]$. Further studies demonstrated that epithelial cells are the primary targets of type III IFNs. Analysis of IFNLR1 expression in isolated mouse cells revealed that keratinocytes and vaginal epithelial cells, but not fibroblasts, were responsive to IFN- $\lambda[12]$. The first in vivo study of IFNLR1 expression in mice was performed in our laboratory [19]. In this study, the response to circulating IFN- $\lambda$ was evaluated in vivo in various mouse organs after plasmid-mediated expression of IFN- $\lambda$ from tibialis muscle cells. The tissues that showed the highest IFN- $\lambda$ responsiveness - stomach, intestine, skin and lung - were epithelium-rich organs. Moreover, the response to IFN- $\lambda$ paralleled IFNLR1 expression in analyzed tissues. In this study, the IFN- $\lambda$ response was analyzed at the cellular level in kidney and brain sections using immunohistofluorescent detection of Mx1, a specific marker of the IFN response. IFN- $\lambda$-responsive cells strikingly differed from IFN- $\alpha$-responsive cells. After IFN- $\lambda$ expression, Mx1-positive cells almost exclusively corresponded to epithelial cells. These included cells forming the convoluted tubules in the kidney and the epithelial cells of the choroïd plexus in the brain. In contrast to IFN- $\lambda$, circulating IFN- $\alpha$ induced a widespread response, which was pronounced in endothelial cells and included most cell types. The epithelial cell specificity of IFN- $\lambda$ responses was subsequently observed in many other organs, such as the lung, intestine, stomach, skin or liver $[15,17,19,20]$ (fig. 3). In humans, constitutive expression of IFNLR1 was also observed in the upper epidermis [21].

The epithelial specificity of the IFN- $\lambda$ response fits with the observed antiviral activity of this IFN in mouse infection models. The high impact of IFN- $\lambda$ observed on rotavirus infection is in good agreement with the tropism exhibited by this virus toward intestinal epithelial cells.

It is noteworthy that the lack of antiviral IFN- $\lambda$ activity observed for some viruses may stem from the use of intraperitoneal inoculation (table 1), which is expected to bypass the barrier made by the epithelial IFN- $\lambda$ response.

\section{Blood Immune Cell Responsiveness to IFN- $\lambda$}

IFNLR1 is thus expressed in a very narrow range of cell types, mainly epithelial cells. However, some responses to IFN- $\lambda$ were also reported in nonepithelial cells and notably in blood cells. Among these cells, conventional (cDCs) and plasmacytoid dendritic cells (pDCs) express IFNLR1 $[22,23]$ and IFN- $\lambda$ was shown to alter their stimulatory properties [24, 25]. B cells and monocytes also express low but significant levels of IFNLR1 but fail to show de-
Table 2. Cells responsive to IFN- $\lambda$

\begin{tabular}{ll}
\hline Cells/organs & Reference No. \\
\hline Responsive cells (mouse) & \\
Cell lines & \\
B16 melanoma cells & 5 \\
PAM212 keratinocyte-like cells & 5 \\
Primary cells & 5 \\
Keratinocytes & 12 \\
Vaginal epithelial cells & 12 \\
pDCs & \\
In vivo & 19,20 \\
Kidney (epithelial cells) & 19 \\
Epithelial cells of the choroid plexus & 17,20 \\
Intestine (epithelial cells) & $13-15,20$ \\
Airway cells & 20 \\
Salivary glands & 30 \\
Cholangiocytes & \\
\hline
\end{tabular}

Responsive cells (human)

Cell lines

$\begin{array}{ll}\text { HepG2, HuH7 (hepatocytes) } & 8,18,52,62 \\ \text { HeLa } & 1 \\ \text { HaCaT (keratinocytes) } & 1 \\ \text { A594 (lung carcinoma cells) } & 1 \\ \text { Intestinal cell lines } & 1,63 \\ \text { imary cells } & \\ \text { Hepatocytes } & 18 \\ \text { Keratinocytes } & 21,62,64 \\ \text { Melanocytes } & 62 \\ \text { Natural killer cells } & 62 \\ \text { Airway epithelial cells } & 65 \\ \text { Nasal epithelial cells } & 66 \\ \text { Astrocytes } & 67 \\ \text { Neurons } & 67 \\ \text { pDCs } & 24 \\ \text { DCs } & 25 \\ \text { Monocytes } & 62 \\ \text { vivo } & \end{array}$

Liver 53, 54

Nonresponsive cells (human and mouse)

Cell lines

Fibroblasts

5

Primary cells

Lymphocytes $\quad 12,26$

Monocytes, macrophages $\quad 5,12,62$

Endothelial cells $\quad 62$

Fibroblasts 12

Adipocytes 62

Splenocytes $\quad 5$

In vivo

Adipocytes 19

Endothelial cells $\quad 19$

Hepatocytes (mouse) $\quad 30$ 
IFN- $\alpha / \beta$
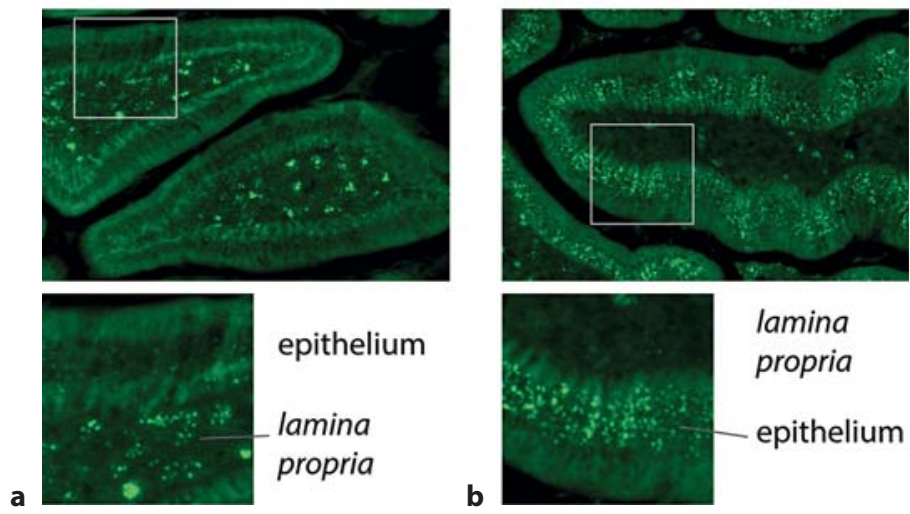

Fig. 3. Epithelial specificity of the IFN- $\lambda$ response in the intestine. Mxl immunostaining in small-intestine sections of mice treated with IFN. a Response to circulating IFN- $\alpha$ in IFNLR $1^{0 / 0}$ mice; $\mathrm{Mx} 1$ is mostly detected in lamina propria cells and little Mx1 expression is detected in epithelial cells. b Response to circulating IFN- $\lambda$ in IFNAR $^{0 / 0}$ mice; Mxl expression is restricted to epithelial cells.

tectable responses. No expression was detected in natural killer and T cells [22].

\section{IFN- $\lambda$ Responses in the Liver}

Hepatocytes are the most abundant cells in the liver and are targeted by several viruses. Because of their epithelial nature, hepatocytes are expected to respond to IFN- $\lambda$. Human hepatocyte cell lines and primary human hepatocytes indeed express the IFN- $\lambda$ receptor and readily respond to IFN- $\lambda[18,26,27]$. Accordingly, IFN- $\lambda$ was shown to restrict HCV replication in hepatoma cell lines. Clinical studies were conducted and IFN- $\lambda$ entered phase 3 clinical trials as a candidate drug against $\mathrm{HCV}$ infection.

In contrast, in mice, response to IFN- $\lambda$ appears to be very weak in the liver and IFNLR1 expression is hardly detectable in this organ $[14,19,20]$. Moreover, in mouse infection experiments, IFN- $\lambda$ was not protective against hepatotropic viruses, such as Lassa fever virus, THOV or Rift Valley fever virus, despite documented production of IFN- $\lambda$ in the liver of infected mice $[14,15]$. Also, in transgenic mice harboring the genome of hepatitis B virus, IFN- $\lambda$ was much less potent than IFN- $\beta$ or IFN- $\gamma$ at reducing viral replication [28].

The above data suggest that IFN $-\lambda$ responses strongly differ between human and mouse hepatocytes. In a model of chimeric mice engrafted with human hepatocytes, the gene encoding IFNLR1 was more strongly expressed in human than in mouse hepatocytes [29]. Our own data support these observations and show that human but not mouse hepatocytes respond to IFN- $\lambda$ in chimeric mice treated with IFN- $\lambda$. In the mouse liver, IFN- $\lambda$ responses were limited to cholangiocytes, the epithelial cells forming the bile ducts [30].

\section{IFN- $\boldsymbol{\lambda}$-Producing Cells}

IFNs are produced after recognition of pathogen-associated molecular patterns by pattern recognition receptors. These receptors include the transmembrane Tolllike receptors (TLRs), cytoplasmic RNA helicases, such as RIG-I, MDA5 and LGP2, and cytoplasmic DNA sensors, such as the recently identified cyclic GMP-AMP synthase [31]. Pattern recognition receptors recognize byproducts of virus replication and trigger the synthesis of IFN. It was reported that type I and type III IFNs were induced by very similar signaling pathways $[1,2,32,33]$ (fig. 1). Indeed, IFN- $\lambda 1$ gene expression largely depends on IRF3 and NF- $\kappa B$, as that of IFN- $\beta$. IFN- $\lambda 2$ and IFN- $\lambda 3$ gene expression rather depends on IRF7, thus resembling that of IFN- $\alpha$ [33] (fig. 1). Yet, the range of IFN- $\lambda$-producing cells may not fully overlap that of type I IFN-producing cells. It was shown in vivo that the balance between type I and type III IFN gene transcription differed in the liver and the brain of infected mice [19].

After infection by HSV-2 or influenza virus, macrophages, which are good IFN- $\alpha / \beta$ producers, did not express IFN- $\lambda[12,34]$. Thus, the cell types producing type I or type III IFNs partially overlap but are not identical. More recent studies have shown that the pathways leading to type I or type III IFN gene expression were not entirely identical, type III IFNs being more dependent on $N F-\kappa B$ than type I IFNs $[35,36]$. Expression of IFN- $\lambda$ has been reported in DCs, respiratory epithelial cells, keratinocytes, hepatocytes, primary neuronal cells and a variety of cell lines [1, 12, 21, 34, 37-42].

\section{IFN- $\lambda$ Production by DCs}

As in the case of type I IFNs, DCs and more particularly pDCs were shown to be important IFN- $\lambda$ producers $[22,38,43]$. Upon viral infection with HSV-1, parapoxvirus or Sendai virus, pDCs produced large amounts of IFN- $\lambda$. However, it was reported that, in response to polyinosinic:polycytidylic acid [poly(I:C)], murine CD8 $a+$ DCs, a subset of cDCs, were the major cell population producing IFN- $\lambda$ [44]. Another study reported that human BDCA3 $+\mathrm{cDCs}$, the counterpart of murine CD $8 \alpha+$ $D C s$, were the major cell population producing IFN $-\lambda$ af- 
ter treatment with poly(I:C) or after coculture with HCVinfected cells [23]. Interestingly, no release of IFN- $\alpha$ was detected from these cells.

In conclusion, both pDCs and cDCs produce IFN $-\lambda$. The fact that cells such as BDCA $3+\mathrm{cDCs}$ produce IFN $-\lambda$ but not IFN- $\alpha$ after stimulation by HCV-infected cells illustrates the subtle differences that exist in the pathways leading to type I or type III IFN production.

\section{IFN- $\lambda$ Production by Epithelial Cells}

Epithelial cells are the main targets of IFN- $\lambda$ activity. Interestingly, several studies suggest that epithelial cells may also act as IFN- $\lambda$-producing cells. IFN- $\lambda$ was, for instance, the major IFN type induced by rhinovirus or influenza A virus infection of primary human airway epithelial cells $[34,45,46]$. In mice, IFN- $\lambda$ production was observed in mouse tracheal epithelial cells in response to influenza A virus infection or poly(I:C) treatment [46].

IFN- $\lambda$ production has also been reported in cultures of primary human keratinocytes in response to poly(I:C) treatment or vesicular stomatitis virus infection [21]. Interestingly, type I IFNs were only detected at very low levels in these cells.

Hepatocytes also produce IFN- $\lambda$. IFN- $\lambda$ mRNA expression was induced in response to experimental $\mathrm{HCV}$ infection of human fetal liver cells or in patients with chronic HCV infection [42, 47]. More recently, in a model of chimeric mice transplanted with human hepatocytes, it was reported that IFN- $\lambda$ was expressed and produced by human hepatocytes at a greater level than IFN- $\alpha$ or IFN- $\beta$ in response to poly(I:C) treatment [29]. Interestingly, in the same study, human IFN- $\lambda$ expression was more strongly induced in HepG2 cells than in HEK293T and MRC-5 cells (kidney and fibroblast cell lines, respectively), whereas the opposite pattern was observed for the expression of IFN- $\beta$. In mice, although the liver has proven to be weakly responsive to IFN- $\lambda$, this IFN was readily expressed in response to virus infection [14].

Finally, IFN- $\lambda$ was also shown to be produced following bacterial infection with Listeria monocytogenes in vivo in the placenta of infected mice and in vitro by human intestinal cell lines, trophoblastic cells and HepG2 cells [48].

\section{Interdependency of Type I and Type III IFNs}

Several ISGs encode factors like RIG-like helicases, TLRs or IRF7, that participate in the signal transduction pathway leading to IFN production. Other ISGs encode proteins like STAT1, SOCS or Usp18, which positively or negatively modulate IFN responses. Since type I and type III IFNs use very similar signal transduction pathways and upregulate the same group of ISGs, it is expected that cross talk exists between these two IFN systems (fig. 1).

Indeed, type III IFN expression was shown to be upregulated by type I IFNs in conditions of virus infection. This was reported by different research groups for $\mathrm{cDCs}$ and macrophages, where treatment with IFN- $\alpha$ prior to virus infection increased IFN- $\lambda$ expression $[39,40,49]$. The same results were obtained when IFN- $\alpha$-treated macrophages were stimulated with TLR agonists [49]. Furthermore, in a coculture between peripheral blood mononuclear cells and HCV-infected Huh7.5 hepatoma cells, Zhang et al. [23] observed increased IFN- $\lambda$ secretion after treatment with IFN- $\alpha$. In conclusion, activation of the type I IFN response clearly primes the cells for IFN- $\lambda$ production. In IFNAR ${ }^{0 / 0}$ mice, virus-induced expression of IFN- $\lambda$ is thus expected to be lower than in wild-type mice. This was indeed observed in IFNAR ${ }^{0 / 0}$ mice infected with HSV-2, Sendai virus or influenza virus $[12,16]$.

Less evidence accumulated until now showing that type III IFNs modulate type I IFN expression. Pretreatment of monocyte-derived macrophages or MDDCs with IFN- $\lambda$ enhanced HSV-1-induced IFN- $\alpha$ and IFN- $\beta$ mRNA expression [39]. Likewise, IFN- $\lambda$ treatment of peripheral blood mononuclear cells or pDCs in coculture with HCV-infected Huh7.5 cells enhanced the production of IFN- $\alpha$ [23]. In contrast, two studies failed to show activation of the type I IFN pathway by IFN- $\lambda$ : after infection with Sendai virus, splenocytes derived from IFNLR $1^{0 / 0}$ mice did not produce less type I or type III IFN than splenocytes derived from wild-type mice [12]; also, IFN- $\lambda$ treatment of human airway epithelial cells infected with influenza A did not increase IFN- $\beta$ expression [34]. However, these negative results can be interpreted as follows: in the first case, very few cells in the splenocyte population are expected to respond to IFN- $\lambda$ and therefore to modulate type I IFN expression; in the second case, epithelial cells such as airway epithelial cells are likely poor IFN- $\beta$ producers, irrespective of priming by IFN.

In conclusion, cross talk exists between the type I and type III IFN systems but it is likely depending on the ability of the cells to produce or respond to specific IFN types.

\section{Potential Therapeutic Use of IFN- $\lambda$}

Type I IFNs are used to treat diseases such as chronic viral hepatitis or multiple sclerosis. However, these treatments have side effects, which might partly relate to the 
Table 3. Association of polymorphism in the region of IFNL3 with sustained virological response to pegIFN- $\alpha$ and ribavirin therapy

\begin{tabular}{|c|c|c|c|c|c|}
\hline $\begin{array}{l}\text { Poly- } \\
\text { morphism }\end{array}$ & $\begin{array}{l}\text { Responder } \\
\text { allele }\end{array}$ & $\begin{array}{l}\text { Nonresponder } \\
\text { allele }\end{array}$ & Location & Comment & $\begin{array}{l}\text { Reference } \\
\text { No. }\end{array}$ \\
\hline rs12979860 & $\mathrm{C}$ & $\mathrm{T}$ & $3 \mathrm{~kb}$ upstream of $I F N L 3$, in intron 1 of IFNL4 & Strong predictor for HCV clearance & 56 \\
\hline rs8099917 & $\mathrm{T}$ & G & $7.5 \mathrm{~kb}$ upstream of $I F N L 3$ & Strong predictor for HCV clearance & 57,58 \\
\hline rs28416813 & $\mathrm{C}$ & G & 37 bp upstream of IFNL3 start codon & In high linkage disequilibrium with rs 12979860 & $56,68,69$ \\
\hline rs8103142 & $\mathrm{T}$ & $\mathrm{C}$ & IFNL3 & In high linkage disequilibrium with rs12979860 & $56,68,69$ \\
\hline rs4803217 & $\mathrm{C}$ & $\mathrm{A}$ & $3^{\prime}$ untranslated region of IFNL3 & İn high linkage disequilibrium with rs12979860 & 68,69 \\
\hline ss469415590 & TT & $\Delta \mathrm{G}$ & IFNL4 (exon 1) & $\begin{array}{l}\Delta \mathrm{G} \text { causes expression of IFN- } \lambda 4 \text {, which is } \\
\text { associated with impaired clearance of HCV } \\
\text { Highly correlated with rs } 12979860[\mathrm{~T}]\end{array}$ & 3 \\
\hline
\end{tabular}

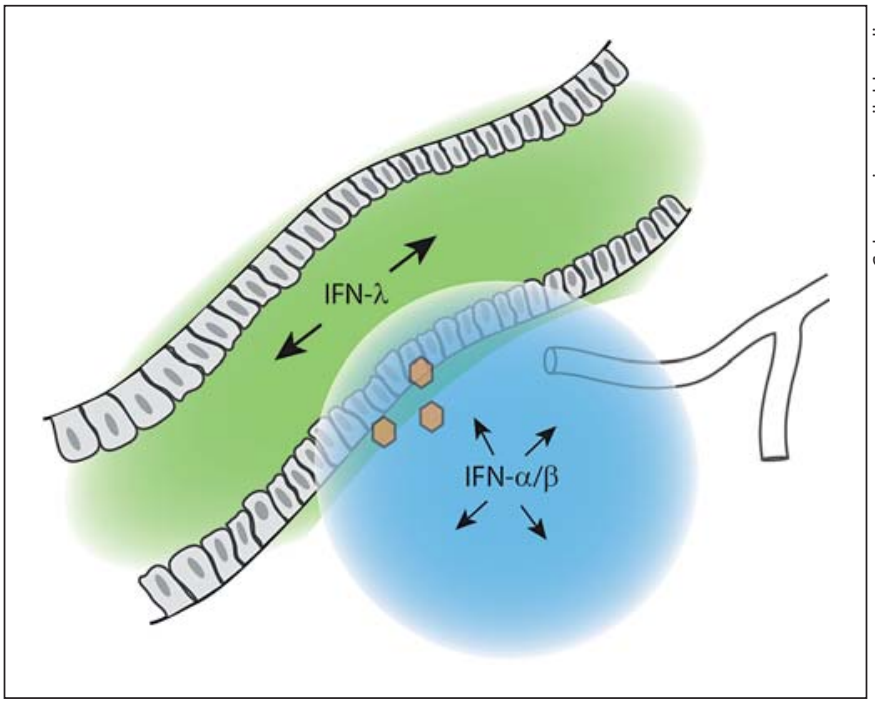

Fig. 4. Model of IFN- $\lambda$ and IFN- $\alpha / \beta$ responses. By being produced by and acting mostly on epithelial cells, IFN- $\lambda$ is expected to contribute to an antiviral response that fits anatomical entities such as the gastrointestinal or respiratory mucosae. By acting on most cells, IFN- $\alpha / \beta$ would act in a rather radial way from the infection focus.

ubiquitous expression of IFNAR. In contrast, the IFN- $\lambda$ receptor distribution is more restricted $[11,19]$. For this reason, fewer side effects may be expected from the use of IFN- $\lambda$.

In cultured cells and in the liver, it was shown that repeated stimulation with IFN- $\alpha$ leads to nonresponsiveness of the cells $[50,51]$. This IFN- $\alpha$ refractoriness is believed to be one of the reasons for the lack of a response of some HCV-infected patients to the treatment [52]. Interestingly, IFN- $\lambda$ did not induce such a refractory state in liver cells and might thus be better adapted for repeated treatment [52].
As discussed above, human hepatocytes appear to be responsive to IFN- $\lambda$, and clinical trials using recombinant IFN $-\lambda$ are currently ongoing for the treatment of chronic $\mathrm{HCV}$ infection. Phase 1 clinical trials have been published $[53,54]$. In these studies, subjects with chronic HCV genotype 1 were administered pegylated IFN (pegIFN)- $\lambda$ with or without ribavirin. pegIFN- $\lambda$ was well tolerated and had antiviral activity against HCV. Side effects, such as aminotransferase, lipase or amylase elevation, were reported. Other adverse events, including fatigue, nausea, myalgia or headache, were reported but seemed to be less frequent than after IFN- $\alpha$ therapy. Importantly, no significant hematological toxicity was detected. In a phase 2 study which has only been published as an abstract, the milder side effects of IFN- $\lambda$ were confirmed [55]. IFN- $\lambda$ has now entered phase 3 clinical trials.

\section{Genetic Polymorphism at the IFN- $\lambda$ Locus and HCV Therapy}

In 2009, genome-wide association studies have identified single nucleotide polymorphisms (SNPs) in the region the IFNL3 gene in humans (table 3). These SNPs, rs12979860 and rs8099917, are located $\sim 3$ and $\sim 8 \mathrm{~kb}$ upstream of IFNL3, respectively [56-58], and are associated with response of $\mathrm{HCV}$ patients to cotreatment with pegIFN- $\alpha$ and ribavirin, and with spontaneous $\mathrm{HCV}$ clearance [56-60]. The rs12979860[T] allele is associated with treatment failure in patients of European ancestry, while the $\mathrm{C}$ allele is associated with a twofold greater rate of sustained virological response [56]. Interestingly, Ge et al. [56] identified two additional SNPs in the IFNL3 gene (SNPs rs28416813 and rs8103142) that are highly associated with rs 12979860 . rs 28416813 consists of a $G \rightarrow C$ substitution 37 bp upstream of the IFNL3 start codon, and rs 8103142 , which occurs in the IFN- $\lambda$ open reading frame 
and results in a nonsynonymous amino acid change at position 70, where arginine is substituted for lysine (K70R). Since then, other SNPs have been identified in the region of the IFNL3 gene and associated with sustained virological response to pegIFN- $\alpha$ /ribavirin therapy. However, the mechanism by which IFN- $\lambda 3$ polymorphisms affect the efficacy of HCV clearance remains to be determined.

Recently, a novel transcript located $3 \mathrm{~kb}$ upstream of IFNL3 was identified as IFNL4 [3]. The SNP rs12979860 is located within intron 1 of this newly identified gene, and a novel marker, ss469415590, was detected in exon 1. ss469415590 is a dinucleotide variant $(\mathrm{TT} \rightarrow \Delta \mathrm{G})$ where $\Delta \mathrm{G}$ results from the deletion of one $\mathrm{T}$ nucleotide (rs67272382) and from a $\mathrm{T} \rightarrow \mathrm{G}$ substitution (rs74597329) [3]. The $\Delta G$ variant creates a frameshift that allows the expression of the IFN- $\lambda 4$ protein. Paradoxically, the expression of this additional IFN- $\lambda$ subtype is associated with impaired clearance of $\mathrm{HCV}$, although IFN- $\lambda 4$ was shown to exhibit a potent inhibitory effect against HCV replication in vitro $[3,4]$. Moreover, IFN- $\lambda 4$ expression is often correlated with the expression of the rs12979860[T] allele, which is also a predictor of a low virological response to HCV treatment [3].

Given the association of SNPs in the IFNL3 locus with spontaneous or drug-mediated viral clearance of $\mathrm{HCV}$, genotyping patients will help to define the therapeutic strategy against this virus.

\section{Concluding Remarks}

More and more evidence accumulates showing that the type I and type III IFN systems are largely nonredundant. IFN- $\lambda$ can induce a longer STAT 1 activation and repeated stimulation of cells with IFN- $\lambda$ does not lead to refractoriness of the cells to subsequent stimulation [52]. Importantly, in vivo, the expression pattern of the IFN- $\lambda$ receptor clearly diverges from that of the IFN- $\alpha / \beta$ receptor. The IFN- $\lambda$ response is predominantly observed in epithelial cells, although some hematopoietic cells were also shown to be responsive. IFN- $\lambda$ thus likely evolved to protect mucosal surfaces against viral infection. This IFN family is probably of utter importance against viruses with a strong epithelial tropism, as was demonstrated in the case of rotavirus [17]. It is worth noting that recent studies show that epithelial cells also act as IFN- $\lambda$-producing cells. The IFN- $\lambda$ system thus likely evolved to offer a local protection that fits epithelium-rich anatomical structures, such as the gastrointestinal or respiratory tract (fig. 4). Protection of epithelial surfaces may also be instrumental in limiting virus transmission by feco-oral or aerosol transmission by reducing both virus excretion and virus entry.

The signal transduction pathway leading to IFN- $\lambda$ production closely resembles that leading to type I IFN production. Yet, some studies suggest that cells producing type I and type III IFNs do not fully overlap and more studies are required to address this issue. Recently, an elegant model of a reporter mouse was developed to identify IFN- $\beta$-producing cells. In these mice, one allele of the IFN- $\beta$-coding region was replaced by the firefly luciferase-coding region, allowing immunostaining and in vivo imaging of IFN- $\beta$-producing cells [61]. The development of such a model to monitor IFN- $\lambda$ expression in vivo would be particularly valuable to complete the understanding of the peculiarities of the IFN- $\lambda$ system.

In summary, the characteristics of type III IFNs render them attractive for targeted antiviral therapy. Phase 3 clinical trials are currently ongoing to test the use of IFN- $\lambda 1$ in therapy against chronic HCV. Interestingly, a number of polymorphisms have been identified in the region of the IFNL3 gene and have been shown to influence the outcome of the treatments against HCV. A new IFN- $\lambda$ subtype, IFN- $\lambda 4$, has been described and is implicated in impaired clearance of $\mathrm{HCV}$ in patients which express the gene [3]. Understanding the underlying mechanisms of such variations in the responsiveness to treatment will help to improve therapies.

\section{Acknowledgements}

P.H. was a research assistant with the Université catholique de Louvain (UCL). This work was supported by the Action de Recherche Concertée (ARC) of the French Community of Belgium, the DIANE programme of the Walloon region and by the Interuniversitary Attraction Poles programme initiated by the Belgian Science Policy Office (IAP-P7/45 BELVIR).

References

\footnotetext{
1 Kotenko SV, Gallagher G, Baurin VV, LewisAntes A, Shen M, Shah NK, Langer JA, Sheikh F, Dickensheets H, Donnelly RP: IFN-lambdas mediate antiviral protection through a distinct class II cytokine receptor complex. Nat Immunol 2003;4:69-77.

-2 Sheppard P, Kindsvogel W, Xu W, Henderson K, Schlutsmeyer S, Whitmore TE, Kuestner R, Garrigues U, Birks C, Roraback J, Ostrander C, Dong D, Shin J, Presnell S, Fox B, Haldeman B, Cooper E, Taft D, Gilbert T, Grant FJ, Tackett M, Krivan W, McKnight G, Clegg C, Foster D, Klucher KM: IL-28, IL-29 and their class II cytokine receptor IL-28R. Nat Immunol 2003;4:63-68.
} 
3 Prokunina-Olsson L, Muchmore B, Tang W, Pfeiffer RM, Park H, Dickensheets H, Hergott D, Porter-Gill P, Mumy A, Kohaar I, Chen S, Brand N, Tarway M, Liu L, Sheikh F, Astemborski J, Bonkovsky HL, Edlin BR, Howell CD, Morgan TR, Thomas DL, Rehermann B, Donnelly RP, O'Brien TR: A variant upstream of IFNL3 (IL28B) creating a new interferon gene IFNL4 is associated with impaired clearance of hepatitis C virus. Nat Genet 2013;45: 164-171.

-4 Hamming OJ, Terczynska-Dyla E, Vieyres G, Dijkman R, Jorgensen SE, Akhtar H, Siupka P, Pietschmann T, Thiel V, Hartmann R: Interferon lambda 4 signals via the IFN $\lambda$ receptor to regulate antiviral activity against $\mathrm{HCV}$ and coronaviruses. EMBO J 2013;32:30553065.

5 Lasfar A, Lewis-Antes A, Smirnov SV, Anantha S, Abushahba W, Tian B, Reuhl K, Dickensheets H, Sheikh F, Donnelly RP, Raveche E, Kotenko SV: Characterization of the mouse IFN-lambda ligand-receptor system: IFNlambdas exhibit antitumor activity against B16 melanoma. Cancer Res 2006;66:44684477.

6 Uze G, Monneron D: IL-28 and IL-29: newcomers to the interferon family. Biochimie 2007;89:729-734.

7 Dumoutier L, Lejeune D, Hor S, Fickenscher $\mathrm{H}$, Renauld JC: Cloning of a new type II cytokine receptor activating signal transducer and activator of transcription (STAT) 1, STAT2 and STAT3. Biochem J 2003:370:391-396.

8 Ank N, West H, Bartholdy C, Eriksson K, Thomsen AR, Paludan SR: Lambda interferon (IFN-lambda), a type III IFN, is induced by viruses and IFNs and displays potent antiviral activity against select virus infections in vivo. J Virol 2006;80:4501-4509.

-9 Dumoutier L, Tounsi A, Michiels T, Sommereyns C, Kotenko SV, Renauld JC: Role of the interleukin (IL)-28 receptor tyrosine residues for antiviral and antiproliferative activity of IL-29/interferon-lambda 1: similarities with type I interferon signaling. J Biol Chem 2004;279:32269-32274.

10 Randall RE, Goodbourn S: Interferons and viruses: an interplay between induction, signalling, antiviral responses and virus countermeasures. J Gen Virol 2008;89:1-47.

-11 Zhou Z, Hamming OJ, Ank N, Paludan SR, Nielsen AL, Hartmann R: Type III interferon (IFN) induces a type I IFN-like response in a restricted subset of cells through signaling pathways involving both the Jak-STAT pathway and the mitogen-activated protein kinases. J Virol 2007;81:7749-7758.

-12 Ank N, Iversen MB, Bartholdy C, Staeheli P, Hartmann R, Jensen UB, Dagnaes-Hansen F, Thomsen AR, Chen Z, Haugen H, Klucher K, Paludan SR: An important role for type III interferon (IFN-lambda/IL-28) in TLR-induced antiviral activity. J Immunol 2008;180: 2474-2485.
3 Mordstein M, Michiels T, Staeheli P: What have we learned from the IL28 receptor knockout mouse? J Interferon Cytokine Res 2010;30:579-584.

14 Mordstein M, Kochs G, Dumoutier L, Renauld JC, Paludan SR, Klucher K, Staeheli P: Interferon-lambda contributes to innate immunity of mice against influenza A virus but not against hepatotropic viruses. PLoS Pathog 2008;4:e1000151.

15 Mordstein M, Neugebauer E, Ditt V, Jessen B, Rieger T, Falcone V, Sorgeloos F, Ehl S, Mayer D, Kochs G, Schwemmle M, Gunther S, Drosten C, Michiels T, Staeheli P: Lambda interferon renders epithelial cells of the respiratory and gastrointestinal tracts resistant to viral infections. J Virol 2010;84:5670-5677. 16 Jewell NA, Cline T, Mertz SE, Smirnov SV,
Flano E, Schindler C, Grieves JL, Durbin RK, Kotenko SV, Durbin JE: Lambda interferon is the predominant interferon induced by influenza A virus infection in vivo. J Virol 2010;84: 11515-11522.

17 Pott J, Mahlakoiv T, Mordstein M, Duerr CU, Michiels T, Stockinger S, Staeheli P, Hornef MW: IFN-lambda determines the intestinal epithelial antiviral host defense. Proc Natl Acad Sci USA 2011;108:7944-7949.

18 Doyle SE, Schreckhise H, Khuu-Duong K, Henderson K, Rosler R, Storey H, Yao L, Liu $\mathrm{H}$, Barahmand-pour F, Sivakumar P, Chan C, Birks C, Foster D, Clegg CH, Wietzke-Braun P, Mihm S, Klucher KM: Interleukin-29 uses a type 1 interferon-like program to promote antiviral responses in human hepatocytes. Hepatology 2006;44:896-906.

19 Sommereyns C, Paul S, Staeheli P, Michiels T: IFN-lambda (IFN-lambda) is expressed in a tissue-dependent fashion and primarily acts on epithelial cells in vivo. PLoS Pathog 2008; 4:e1000017.

20 Pulverer JE, Rand U, Lienenklaus S, Kugel D, Zietara N, Kochs G, Naumann R, Weiss S, Staeheli P, Hauser H, Koster M: Temporal and spatial resolution of type I and III interferon responses in vivo. J Virol 2010;84:8626-8638.

21 Zahn S, Rehkamper C, Kummerer BM, Ferring-Schmidt S, Bieber T, Tuting T, Wenzel J: Evidence for a pathophysiological role of keratinocyte-derived type III interferon (IFNlambda) in cutaneous lupus erythematosus. J Invest Dermatol 2011;131:133-140.

22 Yin Z, Dai J, Deng J, Sheikh F, Natalia M, Shih T, Lewis-Antes A, Amrute SB, Garrigues U, Doyle S, Donnelly RP, Kotenko SV, Fitzgerald-Bocarsly P: Type III IFNs are produced by and stimulate human plasmacytoid dendritic cells. J Immunol 2012;189:2735-2745.

23 Zhang S, Kodys K, Li K, Szabo G: Human type 2 myeloid dendritic cells produce interferonlambda and amplify interferon-alpha in response to hepatitis C virus infection. Gastroenterology 2013;144:414.e7-425.e7.

24 Megjugorac NJ, Gallagher GE, Gallagher G: Modulation of human plasmacytoid DC function by IFN-lambda1 (IL-29). J Leukoc Biol 2009;86:1359-1363.
25 Mennechet FJ, Uze G: Interferon-lambdatreated dendritic cells specifically induce proliferation of FOXP3-expressing suppressor T cells. Blood 2006;107:4417-4423.

26 Dickensheets H, Sheikh F, Park O, Gao B, Donnelly RP: Interferon-lambda (IFN-lambda) induces signal transduction and gene expression in human hepatocytes, but not in lymphocytes or monocytes. J Leukoc Biol 2013;93:377-385.

27 Diegelmann J, Beigel F, Zitzmann K, Kaul A, Goke B, Auernhammer CJ, Bartenschlager R, Diepolder HM, Brand S: Comparative analysis of the lambda-interferons IL-28A and IL29 regarding their transcriptome and their antiviral properties against hepatitis $C$ virus. PloS One 2010;5:e15200.

28 Pagliaccetti NE, Chu EN, Bolen CR, Kleinstein SH, Robek MD: Lambda and alpha interferons inhibit hepatitis B virus replication through a common molecular mechanism but with different in vivo activities. Virology 2010;401:197-206.

29 Nakagawa S, Hirata Y, Kameyama T, Tokunaga Y, Nishito Y, Hirabayashi K, Yano J, Ochiya T, Tateno C, Tanaka Y, Mizokami M, Tsukiyama-Kohara K, Inoue K, Yoshiba M, Takaoka A, Kohara M: Targeted induction of interferon-lambda in humanized chimeric mouse liver abrogates hepatotropic virus infection. PloS One 2013;8:e59611.

30 Hermant P, Demarez C, Mahlakõiv T, Staeheli P, Meuleman P, Michiels T: Human but not mouse hepatocytes respond to interferonlambda in vivo. PLoS One 2014;9:e87906.

-31 Sun L, Wu J, Du F, Chen X, Chen ZJ: Cyclic GMP-AMP synthase is a cytosolic DNA sensor that activates the type I interferon pathway. Science 2013;339:786-791.

- 32 Onoguchi K, Yoneyama M, Takemura A, Akira S, Taniguchi T, Namiki H, Fujita T: Viral infections activate types I and III interferon genes through a common mechanism. J Biol Chem 2007;282:7576-7581.

33 Osterlund PI, Pietila TE, Veckman V, Kotenko SV, Julkunen I: IFN regulatory factor family members differentially regulate the expression of type III IFN (IFN-lambda) genes. J Immunol 2007;179:3434-3442.

34 Wang J, Oberley-Deegan R, Wang S, Nikrad M, Funk CJ, Hartshorn KL, Mason RJ: Differentiated human alveolar type II cells secrete antiviral IL-29 (IFN-lambda 1) in response to influenza a infection. J Immunol 2009; 182:1296-1304.

35 Iversen MB, Ank N, Melchjorsen J, Paludan SR: Expression of type III interferon (IFN) in the vaginal mucosa is mediated primarily by dendritic cells and displays stronger dependence on NF-kappaB than type I IFNs. J Virol 2010;84:4579-4586.

36 Thomson SJ, Goh FG, Banks H, Krausgruber T, Kotenko SV, Foxwell BM, Udalova IA: The role of transposable elements in the regulation of IFN-lambdal gene expression. Proc Natl Acad Sci USA 2009;106:11564-11569. 
-37 Zhou L, Wang X, Wang YJ, Zhou Y, Hu S, Ye L, Hou W, Li H, Ho WZ: Activation of tolllike receptor-3 induces interferon-lambda expression in human neuronal cells. Neuroscience 2009;159:629-637.

- 38 Coccia EM, Severa M, Giacomini E, Monneron D, Remoli ME, Julkunen I, Cella M, Lande R, Uze G: Viral infection and Toll-like receptor agonists induce a differential expression of type I and lambda interferons in human plasmacytoid and monocyte-derived dendritic cells. Eur J Immunol 2004;34:796-805.

39 Melchjorsen J, Siren J, Julkunen I, Paludan SR, Matikainen S: Induction of cytokine expression by herpes simplex virus in human monocyte-derived macrophages and dendritic cells is dependent on virus replication and is counteracted by ICP27 targeting NF-kappaB and IRF-3. J Gen Virol 2006;87:10991108.

40 Osterlund P, Veckman V, Siren J, Klucher KM, Hiscott J, Matikainen S, Julkunen I: Gene expression and antiviral activity of alpha/beta interferons and interleukin-29 in virus-infected human myeloid dendritic cells. J Virol 2005;79:9608-9617.

-41 Contoli M, Message SD, Laza-Stanca V, Edwards MR, Wark PA, Bartlett NW, Kebadze T, Mallia P, Stanciu LA, Parker HL, Slater L, Lewis-Antes A, Kon OM, Holgate ST, Davies DE, Kotenko SV, Papi A, Johnston SL: Role of deficient type III interferon-lambda production in asthma exacerbations. Nat Med 2006; 12:1023-1026.

-42 Marukian S, Andrus L, Sheahan TP, Jones CT, Charles ED, Ploss A, Rice CM, Dustin LB: Hepatitis $C$ virus induces interferon-lambda and interferon-stimulated genes in primary liver cultures. Hepatology 2011;54:19131923.

-43 Megjugorac NJ, Gallagher GE, Gallagher G: IL-4 enhances IFN-lambda1 (IL-29) production by plasmacytoid DCs via monocyte secretion of IL-1Ra. Blood 2010;115:41854190.

-44 Lauterbach H, Bathke B, Gilles S, Traidl-Hoffmann C, Luber CA, Fejer G, Freudenberg MA, Davey GM, Vremec D, Kallies A, Wu L, Shortman K, Chaplin P, Suter M, O’Keeffe M, Hochrein H: Mouse CD8alpha+ DCs and human BDCA3+ DCs are major producers of IFN-lambda in response to poly IC. J Exp Med 2010;207:2703-2717.

45 Khaitov MR, Laza-Stanca V, Edwards MR, Walton RP, Rohde G, Contoli M, Papi A, Stanciu LA, Kotenko SV, Johnston SL: Respiratory virus induction of alpha-, beta- and lambda-interferons in bronchial epithelial cells and peripheral blood mononuclear cells. Allergy 2009;64:375-386.

46 Ioannidis I, Ye F, McNally B, Willette M, Flano E: Toll-like receptor expression and induction of type I and type III interferons in primary airway epithelial cells. J Virol 2013;87: 3261-3270.
7 Dolganiuc A, Kodys K, Marshall C, Saha B, Zhang S, Bala S, Szabo G: Type III interferons, IL-28 and IL-29, are increased in chronic $\mathrm{HCV}$ infection and induce myeloid dendritic cell-mediated FoxP3+ regulatory T cells. PloS One 2012; 7:e44915.

48 Bierne H, Travier L, Mahlakoiv T, Tailleux L, Subtil A, Lebreton A, Paliwal A, Gicquel B, Staeheli P, Lecuit M, Cossart P: Activation of type III interferon genes by pathogenic bacteria in infected epithelial cells and mouse placenta. PloS One 2012;7:e39080.

49 Siren J, Pirhonen J, Julkunen I, Matikainen S: IFN-alpha regulates TLR-dependent gene expression of IFN-alpha, IFN-beta, IL-28, and IL-29. J Immunol 2005;174:1932-1937.

50 Larner AC, Chaudhuri A, Darnell JE Jr: Transcriptional induction by interferon. New protein(s) determine the extent and length of the induction. J Biol Chem 1986;261:453-459.

51 Sarasin-Filipowicz M, Wang X, Yan M, Duong FH, Poli V, Hilton DJ, Zhang DE, Heim MH: Alpha interferon induces long-lasting refractoriness of JAK-STAT signaling in the mouse liver through induction of USP18/ UBP43. Mol Cell Biol 2009;29:4841-4851.

52 Makowska Z, Duong FH, Trincucci G, Tough DF, Heim MH: Interferon-beta and interferon-lambda signaling is not affected by interferon-induced refractoriness to interferonalpha in vivo. Hepatology 2011;53:11541163.

53 Muir AJ, Shiffman ML, Zaman A, Yoffe B, de la Torre A, Flamm S, Gordon SC, Marotta P, Vierling JM, Lopez-Talavera JC, ByrnesBlake K, Fontana D, Freeman J, Gray T, Hausman D, Hunder NN, Lawitz E: Phase 1b study of pegylated interferon lambda 1 with or without ribavirin in patients with chronic genotype 1 hepatitis $C$ virus infection. Hepatology 2010;52:822-832.

54 Ramos EL: Preclinical and clinical development of pegylated interferon-lambda 1 in chronic hepatitis C. J Interferon Cytokine Res 2010;30:591-595.

55 Zeuzem S, Arora S, Bacon B, Box T, Charlton M, Diago M, Dieterich D, Esteban Mur R, Everson G, Fallon M, Ferenci P, Flisiak R, George J, Ghalib R, Gitlin N, Gladysz A, Gordon S, Greenbloom S, Hassanein T, Jacobson I, Jeffers L, Kowdley K, Lawitz E, Lee S, Leggett B, Lueth S, Nelson D, Pockros P, RodriguezTorres M, Rustgi V, Serfaty L, Sherman M, Shiffman M, Sola R, Sulkowski M, Vargas H, Vierling J, Yoffe B, Ishak L, Fontana D, Xu D, Lester J, Gray T, Horga A, Hillson J, Ramos E, Lopez-Talavera JC, Muir A: Pegylated interferon-lambda (pegIFN $\lambda$ ) shows superior viral response with improved safety and tolerability versus pegIFN- $\alpha 2$ in $\mathrm{HCV}$ patients (G1/2/3/4): EMERGE phase IIB through week 12. J Hepatol 2011;54:S538-S539.
56 Ge D, Fellay J, Thompson AJ, Simon JS, Shianna KV, Urban TJ, Heinzen EL, Qiu P, Bertelsen AH, Muir AJ, Sulkowski M, McHutchison JG, Goldstein DB: Genetic variation in IL28B predicts hepatitis C treatmentinduced viral clearance. Nature 2009;461: 399-401.

57 Suppiah V, Moldovan M, Ahlenstiel G, Berg T, Weltman M, Abate ML, Bassendine M, Spengler U, Dore GJ, Powell E, Riordan S, Sheridan D, Smedile A, Fragomeli V, Muller T, Bahlo M, Stewart GJ, Booth DR, George J: IL28B is associated with response to chronic hepatitis $\mathrm{C}$ interferon-alpha and ribavirin therapy. Nat Gen 2009;41:1100-1104.

-58 Tanaka Y, Nishida N, Sugiyama M, Kurosaki M, Matsuura K, Sakamoto N, Nakagawa M, Korenaga M, Hino K, Hige S, Ito Y, Mita E, Tanaka E, Mochida S, Murawaki Y, Honda M, Sakai A, Hiasa Y, Nishiguchi S, Koike A, Sakaida I, Imamura M, Ito K, Yano K, Masaki $\mathrm{N}$, Sugauchi F, Izumi N, Tokunaga K, Mizokami M: Genome-wide association of IL28B with response to pegylated interferon-alpha and ribavirin therapy for chronic hepatitis $\mathrm{C}$. Nat Genet 2009;41:1105-1109.

59 Rauch A, Kutalik Z, Descombes P, Cai T, Di Iulio J, Mueller T, Bochud M, Battegay M, Bernasconi E, Borovicka J, Colombo S, Cerny A, Dufour JF, Furrer H, Gunthard HF, Heim M, Hirschel B, Malinverni R, Moradpour D, Mullhaupt B, Witteck A, Beckmann JS, Berg T, Bergmann S, Negro F, Telenti A, Bochud PY; Swiss Hepatitis C Cohort Study, Swiss HIV Cohort Study: Genetic variation in IL28B is associated with chronic hepatitis C and treatment failure: a genome-wide association study. Gastroenterology 2010;138: 1338-1345, 1345.e1-1345.e7.

60 Thomas DL, Thio CL, Martin MP, Qi Y, Ge D, O'Huigin C, Kidd J, Kidd K, Khakoo SI, Alexander G, Goedert JJ, Kirk GD, Donfield SM, Rosen HR, Tobler LH, Busch MP, McHutchison JG, Goldstein DB, Carrington M: Genetic variation in IL28B and spontaneous clearance of hepatitis $C$ virus. Nature 2009;461:798-801.

61 Lienenklaus S, Cornitescu M, Zietara N, Lyszkiewicz M, Gekara N, Jablonska J, Edenhofer F, Rajewsky K, Bruder D, Hafner M, Staeheli $\mathrm{P}$, Weiss S: Novel reporter mouse reveals constitutive and inflammatory expression of IFN-beta in vivo. J Immunol 2009;183:32293236.

62 Witte K, Gruetz G, Volk HD, Looman AC, Asadullah K, Sterry W, Sabat R, Wolk K: Despite IFN-lambda receptor expression, blood immune cells, but not keratinocytes or melanocytes, have an impaired response to type III interferons: implications for therapeutic applications of these cytokines. Genes Immun 2009;10:702-714. 
63 Brand S, Beigel F, Olszak T, Zitzmann K, Eichhorst ST, Otte JM, Diebold J, Diepolder H, Adler B, Auernhammer CJ, Goke B, Dambacher J: IL-28A and IL-29 mediate antiproliferative and antiviral signals in intestinal epithelial cells and murine CMV infection increases colonic IL-28A expression. Am J Physiol Gastrointest Liver Physiol 2005; 289:G960-G968.

64 Wolk K, Witte K, Witte E, Proesch S, SchulzeTanzil G, Nasilowska K, Thilo J, Asadullah K, Sterry W, Volk HD, Sabat R: Maturing dendritic cells are an important source of IL-29 and IL-20 that may cooperatively increase the innate immunity of keratinocytes. J Leukoc Biol 2008;83:1181-1193.
65 Ioannidis I, McNally B, Willette M, Peeples ME, Chaussabel D, Durbin JE, Ramilo O, Mejias A, Flano E: Plasticity and virus specificity of the airway epithelial cell immune response during respiratory virus infection. J Virol 2012;86:5422-5436.

66 Okabayashi T, Kojima T, Masaki T, Yokota S, Imaizumi T, Tsutsumi $\mathrm{H}$, Himi T, Fujii $\mathrm{N}$, Sawada N: Type-III interferon, not type-I, is the predominant interferon induced by respiratory viruses in nasal epithelial cells. Virus Res 2011;160:360-366.

67 Li J, Hu S, Zhou L, Ye L, Wang X, Ho J, Ho W: Interferon lambda inhibits herpes simplex virus type I infection of human astrocytes and neurons. Glia 2011;59:58-67.
68 de Castellarnau M, Aparicio E, Parera M, Franco S, Tural C, Clotet B, Martinez MA: Deciphering the interleukin $28 \mathrm{~B}$ variants that better predict response to pegylated interferon- $\alpha$ and ribavirin therapy in HCV/ HIV-1 coinfected patients. PloS One 2012; 7:e31016.

69 di Iulio J, Ciuffi A, Fitzmaurice K, Kelleher D, Rotger M, Fellay J, Martinez R, Pulit S, Furrer H, Gunthard HF, Battegay M, Bernasconi E, Schmid P, Hirschel B, Barnes E, Klenerman P, Telenti A, Rauch A; Swiss HIV Cohort Study: Estimating the net contribution of interleukin-28B variation to spontaneous hepatitis $\mathrm{C}$ virus clearance. Hepatology 2011;53:14461454. 